DOI: $10.14451 / 2.142 .54$

\title{
СОВРЕМЕННЫЕ ТЕНДЕНЦИИ РОССИЙСКОГО БАНКОВСКОГО СЕКТОРА
}

\author{
(c) 2020 Левченко Лариса Владимировна \\ кандидат экономических наук, доцент \\ Самарский государственный экономический университет, Россия, Самара \\ (c) 2020 Силантьев Юрий Сергеевич \\ магистрант 2 курса \\ Самарский государственный экономический университет, Россия, Самара
}

В данной статье рассмотрена динамика изменения числа участников, финансовых инструментов на отечественном банковском рынке. Обособлены ключевые факторы трансформации кредитнофинансовых институтов.

Ключевые слова: банковская система, операционная прибыль, процентная ставка, финансовый актив, финансовая технологий.

По данным сайта ЦБ РФ по состоянию на январь 2020 года число зарегистрированных кредитных учреждений достигло 561 финансовых институтов [1]. Порядка 469 кредитных организаций обладают возможностью и правом осуществлять привлечение средств в депозиты, 151 организация имеет право осуществлять операции по торговле с драгоценными металлами [2]. На рисунке 1 представлены структура официально зарегистрированных и действующих кредитных организаций за период (2015-2018 гг.)

Несмотря на отрицательные последствия международного кризиса для экономики РФ и в частности ее банковского сектора открылись новые пути получения операционной прибыли, а именно произошло резкое развитие удаленных каналов обслуживания. Отечественная экономика смогла встать в число лидеров по развитию операций с цифровыми финансовыми активами

в европейском, ближневосточном и африканском регионах [7].

Следует указать, что подавляющая часть активных пользователей, использующих каналы дистанционного банковского обслуживания используют функционал таких систем для анализа остатка на расчетном счете и остатка планируемой к погашению ссуды. Самая меньшая доля осуществляемых процедур - операции с торговлей и безмаржинальным обменом валютой (подобных сделок порядка 15-17\%), однако доля подобных операций в 2019 году по сравнению с 2017 годом увеличилась примерно на 11\% [3]. В настоящее время наблюдается тенденция роста числа совершаемых операций с использованием онлайн-сервисов. Большая часть технологий приобретается под лицензией за рубежом. Хотя, существуют и очень перспективные отечественные разработки от Яндекса - голосовой помощ-

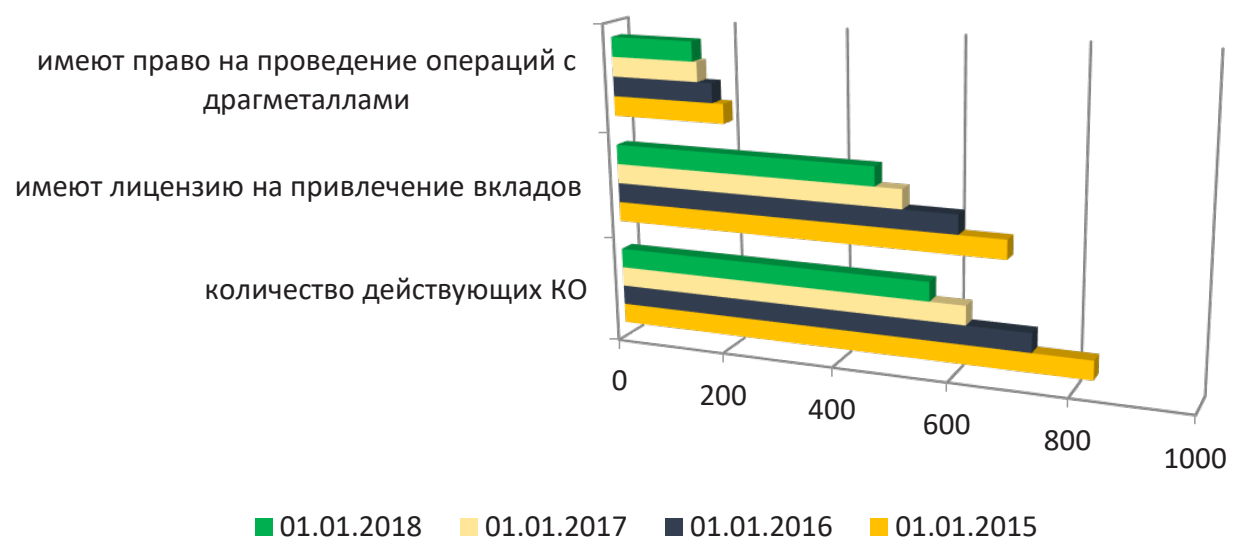

Pис. 1. Динамика численности кредитно-финансовых институтов, обладающих лицензией ЦБ РФ на осуществление банковской деятельности Источник: Официальный сайт Центрального банка Российской Федерации 
ник «АЛИСА» и от Mail.ru - «Маруся» [4].

Ранее, наиболее популярным кредитным продуктов в розничном сегменте банковского бизнеса в России являлись банковские карты [5]. Однако рост ставки рефинансирования и ее регулярный пересмотр повлекли рост ставок по действующим и вновь заключаемым кредитным договорам. Это сказалось на сокращении использования данного типа банковского продукта.

Также, немаловажным аспектом слабого развития онлайн-банкинга в отечественной экономике является слабая законодательная база и поддержка проводимых операций. Определенные сложности банки испытывают с организациями, в рамках взаимодействия в кредитном процессе, не относящихся к банковскому бизнесу и выпадающих из сферы регулирования, регуляторов банковского рынка.

Можно с определенной степенью говорить о воздействии на работу цифрового банкинга самих интернет-провайдеров. Поскольку от качества работы последних зависит стабильность работы банков, скорость и надежность совершаемых ими операций и деловая репутация кредитного учреждения в целом [6].

Несмотря на то, что в настоящее время, благодаря разнообразным правительственным мерам, национальная банковская система обладает возможностью к сопротивлению вводимых и поддерживаемых санкций, проблемы с финансированием и получением доступа к интернациональным кредитам сохраняются и ситуация, исходя из последних событий, имеет место ухудшаться. В складывающейся парадигме институтам банковского сектора необходимо проводить переориентацию на внутренний рынок - поиск внутренних клиентов и активное участие в повышение доходности их деятельности в целях будущего наращивания качественного высокодоходного портфеля.

\section{Библиографический список}

1. Вайпан В.А., Егорова М.А. Правовое регулирование экономических отношений в современных условиях развития цифровой экономики. Монография. Изд-во: Юстицинформ, Москва. 2019. - 376 С.

2. Филиппов А. Е. Отдельные правовые аспекты регулирования оборота цифровых активов в России и за рубежом // Арбитражные споры. 2018. № 4. С. 23-28.

3. Курманова Д. А. Финансовые технологии на розничном рынке банковских услуг // Вестник УГНТУ. Наука, образование, экономика. Серия экономика. № 1 (27), 2019. С. 60-67.

4. План мероприятий («дорожная карта») по реализации основных направлений развития финансового рынка Российской Федерации на период 2019-2021 годов [Электронный ресурс]. Режим доступа: https://www. garant.ru/products/ipo/prime/doc/72117776/\#review.

5. Храпченко Л.. Структурированные продукты в России // Forbes, российское издание. - 2016. - № 7 (28) - с. 100-102.

6. Нетунаев Е. Б. Причины формирования финансовых пузырей и методы борьбы с ними на развивающихся фондовых рынках // Вестник СПбГУ. Менеджмент. 2018. Т.17, № 3. - С. 359-383.

7. Рязанова О.Е. Институт промышленной собственности в инновационной экономике. М.,2014.- С.73-77. 